\title{
Predictive Analysis Linked to Asset Liability Management for the Success or Failure of Banks
}

\author{
Effulgence \\ Vol. 20, No. 1 \\ January - June 2022 \\ Rukmini Devi Institute of Advanced Studies \\ E-mail : effulgence@rdias.ac.in, Website : www.rdias.ac.in \\ http://effulgence.rdias.ac.in/user/default.aspx \\ https://dx.doi.org/10.33601/effulgence.rdias/v20/i1/2022/38-53
}

\section{Dr. Shikha Agarwal ${ }^{1} \square$ \\ Dr. Sushil Kumar ${ }^{2}$ \\ Dr. Shweta Arora ${ }^{3}$}

\begin{abstract}
With the onset ofliberalization, Indian banks are presently more vulnerable to ambiguity and to international competition. This creates it subservient to have appropriate asset liability management system in place. Some banks are closed down due to mis management of assets with liabilities, bad non-performing assets, loss due to fluctuating interest rates, poor investment portfolio and many others. Various parameters related to asset, liability, loan, deposit, capital adequacy, liquidity which are having relevance to the sustenance of the banks are studied deeply with asset liability management as the background for 10 years for 10 private sector and 10 public sector banks. These parameters are woven in a predictive model based on Linear discriminant function analysis (i.e., discriminant analysis).It executes a multivariate test of differences among groups. In addition, discriminant analysis is helpful in determining the least number of dimensions needed to describe these alterations on descriptive analysis which serves as a benchmark for the banks and prevents them from falling.
\end{abstract}

Keywords: Banks, asset liability management, asset composition, liability composition, capital adequacy, net interest margin, SPSS)

\section{INTRODUCTION}

B anks are important organizations of economic set up of every country. A well-defined and developed banking structure is considered as the most important for the sustained economic development of a country. This sector reflects the larger economy - its linkages to all sectors make it a proxy for whatever happens in the overall economy. "In fact, the Indian banking sector today has the same sense of excitement and opportunity, as is apparent in the Indian economy." (Dhawan 2016). "The disintermediation, blurring of conventional roles and limits, has directed to the complete transformation of the Indian banking sector. The ongoing growth and developments in Indian

1. Assistant Professor, Indirapuram Institute of Higher Studies, Ghaziabad, dr.shikha.iihs@gmail.com

2. Associate Professor, JaganNath University, dravidsushil4@gmail.com

3. Assistant Professor, Indirapuram Institute of Higher Studies, Ghaziabad, arora4014@gmail.com 
industries and government and the integration of our economy with the global economy also offer myriad opportunities to the banking sector." (Kamath, 2003) “A.P.J. Abdul Kalam, earlier President of India, delineated his dream to change India into a affluent nation by 2020 through the recognition of "that ideal plentitude" for the Indians and advised the banking community to be the frontline in this national development process." (Kalam, 1998).

There is advent of newer models, methods, and techniques to control the numerous types of risks affecting the banks. Asset Liability Management deals with these risks by analyzing and thereafter controlling asset liability disparities in the maturity period. It is an inclusive and dynamic method to measure, monitor, and manage the various risks of a banking institution. It is a threefold mechanism where it identifies various risk parameters, measures them, and then frames risk policies accordingly to counter them. This research is started to comprehend the thought of Asset Liability Management and claim of it in Viable Banks in India. The research is a comparative study done on selected Indian commercial banks.

Important works have been carried out in the arena of asset liability management by Gardner and Plants (1991) , Haslem et al (1999), Nathan Vaidya (1999), Vaidya and Shahi's (2001), Agrawal Nimisha and Agrawal C. P. (2017) and by many others. Maximum of the studies are done for either private or public sector banks, but this study apart from comparison also focuses on the main core reason of the problem for sample banks. This study might add and form the base for advance research into the presentation of Asset Liability Management approaches in the banking industry. This can go a lengthy way in coming up with even enhanced and more proficient plans that are specific to diverse bank sizes, markets in which they function balancing of the diverse risk appetites that may be present within the different banks. Generally, this study will contribute to the other research on the consequence of maintaining a appropriate equilibrium between assets and liability and risk reduction.

The uniqueness of the research is a model based on Discriminant Analysis which helps banks predicts parameters important to banks so that bank failures are averted. Detailed comparison of the public sector (PSB) and private sector (PVB) banks along with the valid recommendations for the nonperforming banks is the key highlight of the study.

This study is built on the various rare studies on the basis of specific Indian banking sector and also foreign research papers and articles that focus on practices of Asset Liability Management such as gap analysis and its relationship with liquidity and profitability. The research papers are empirical, qualitative, quantitative, compare contrast papers. Some papers focus on public and private sector individually and some focus on comparison of both the types of banks. The research articles have also used models based on regression equation, statistical analysis tools such as T-test for hypothesis testing. The varied research and scholarly articles provide deep insight into the understanding of the concept and acts as supportive reports.

The foremost objective of this study is to analyze the key indicators of bank's performance which when trapped beforehand can save the bank from failure. Certain factors govern the performance or the health of the banks and these factors if taken care of beforehand can save the bank from failure .Keeping this concept a predictive model has been designed with the data of 20 commercial banks (10 private sector and 10 public sector) for the time period from 2009 to 2018 with the help of Discriminant Analysis using SPSS.

The paper builds the model using Discriminant Analysis using SPSS and the descriptive statistics is generated after variable input. The Discriminant Linear Equation sums up the model and Descriptive 
Statistics are generated giving critical regions. The flow chart helps in the navigation of individual bank to identify whether the bank is in risk state, requires critical risk assessment or needs improvement.

\section{LITERATURE REVIEW}

Srivastava Shashi and Srivastava Divya (2015) the current examination paper endeavored to give a thorough profile of Interest Rate Risk in State Bank of India and ICICI Bank, the significant parts in Public and Private Sector Bank separately. Resource Liability Mismatch, Sensitivity Analysis, and Gap strategies were utilized to quantify Interest Rate Risk. Further, the investigation likewise centered on Interest Rate Risk relieving devices like Asset Liability the executives and Interest Rate Derivatives received by these banks. The findings revealed that ICICI Bank is more exposed to interest rate risk as compared to SBI.

Obarin Lilian Akwii (2015) taking into account that the Kenyan financial area has been serious and ALM is basic for the achievement of monetary foundations, this clear study (thesis) set off to decide the impact of resource risk the board on productivity of business banks in Kenya. The examination gathered auxiliary information from distributed budget reports of 44 business banks in Kenya for the period 2010 to 2014. The relapse examination sets up that 47.7 percent of varieties in monetary execution proxied by ROA were clarified by varieties in the investigation free factors specifically, Size, Capital construction, and resource responsibility the executives position of the bank.

Shetty (2016) directed an investigation on the openness of private banks to resource obligation the executives. This paper endeavored to evaluate the liquidity hazard that every one of the five private area banks are presented to spread over a period from 2011 to 2015. The finding from the investigation uncovered that banks have been exposed to liquidity hazard. The examination additionally demonstrated that HDFC bank and ICICI bank have better ALM system.

Sharma Deepak Kumar and Saharan Anju (2016) the investigation broke down the liquidity of the chosen nationalized banks in India. The current investigation utilized an Exploratorium-descriptive examination plan. Test of the ten nationalized banks i.e., Andhra Bank, Bank of Baroda, Bank of India, Canara Bank, Corporation Bank, Dena Bank, Indian Overseas Bank, Indian Bank, Union Bank, United Bank of India has been utilized and the time of the investigation is 2004-05 to 2013-14. The examination depends on auxiliary information which has been gathered from the Indian Banks' Association, Reserve Bank of India, site, and CMIE Prowess data set. Average and ranking are used as a tool and techniques of analysis.

Pakira Sanjib Kumar (2016) the specialist investigated the development rate in SBI and HDFC Bank restricted as both the banks are goliath banks in the general population and private area, so a Comparative investigation of Growth examination of both the banks for a time of 10 years is made. The principle boundaries of development in banks were Reserve and Surplus development (RES), Advance development (ADV), Investment development (INV), Interest Earned development ( IE),Operating Expenses development (OE), Equity Dividend development (ED), Net benefit development (NP) and EPS development (EPS) and Descriptive insights shows that the development execution of HDFC bank is satisfying than SBI during the period under investigation and the different relapse test results uncover that as far as the boundaries characterized HDFC Bank has performed obviously superior to SBI Bank.

Shanthana Lakshmi. M (2016) the third portion of the Basel Accords Basel III was created because of the lacks in monetary guideline uncovered by the last part of the 2000s monetary emergency. Hold Bank of India has fixed a cutoff time of March 2018 for Indian banks to finish their compliance to the Basel-III standards. This paper has been separated 
into three stages. The primary stage tells about the example banks taken for investigation. The subsequent stage is trying the meaning of Tier 1 and Tier 2 Capital and the last stage has the finish of how these banks can accomplish the Basel III standards.

Singh, K. And Gupta, R. (2017) This study analyses a comparative position of various strategies adopted by individual Central banks and policy changes included in their monetary policy to implement the Basel 3 provisions in the phased manner. The study concludes that the developed countries are relatively in a comfortable position as compared to developing economies.

Umarani $R$ and Jayanthi $M$ (2017) contemplated the liquidity Risk in SBI and partner banks in India, by utilizing Gap Analysis Technique (development profiling). Utilizing openly accessible data, this paper endeavors to survey the liquidity hazard conveyed by the example banks in the year 20112012. The discoveries uncovered that the banks were presented to liquidity hazard.

Lemma Seblewongel (2017) the motivation behind this examination (Thesis) was to research the effect of resource risk the executives on the benefit of banks in Ethiopia by utilizing board information of seven business banks from the year 2005 to 2016. The examination utilized a quantitative exploration approach and dissected by utilizing relapse models Moreover, ROA, were utilized to gauge productivity, the Fixed Effect relapse model was applied to research the effect of capital ampleness, resource quality, functional effectiveness, liquidity, pay enhancement, and bank size. The finding of the examination showed that pay enhancement, liquidity, the meaning of bank size genuinely, and beneficial outcome on banks benefit.

Tee (2017) assessed on resource obligation the executives and the benefit of recorded banks in Ghana. The fundamental plan of this paper is to assess the impact of resource and obligation the board on the benefit of recorded banks in Ghana.
Multiple linear regression utilized by mulling over ROA as the reliant variable, and TAS (the total asset) and TLT (the total liability) addressing the resource and responsibility blend of the banks.

Devendra M. and Prof. Reddy Mohan P. (2017) the current exploration illustrated predominantly on the estimation of loan fee hazard in open area banks which incorporate Bank of India and Andhra Bank and Private area banks which incorporate Axis Bank and HDFC Bank utilizing the GAP investigation model.

BharathVajan R. and Thooyamani K.P. (2017) in this examination the bank dealt with the danger of Asset risk difference by coordinating with the resources and liabilities as indicated by the development design or the comparing time frame [10-15], by supporting and by securitization. The paper contemplated liquidity through specific proportions.

Lekhi Pooja (2017) proposal was submitted to PTU in the year 2017 and zeroed in on to consider patterns in the piece of resources in chose banks, to direct advances quality audit in the chosen public area and private area banks, inspect the nature of speculation portfolio in chose banks and study the effect of resource quality on the benefit of chosen banks.

Joshi1 P. and R. V. Sontakay (2017) announced an overview of different ALM procedures in the writing, meaning to monetary strength. The review assists arising manages an account with choosing the distinctive ALM measure utilized by the financial enterprises and to choose the proficient interaction out of the detailed strategies.

Agrawal Nimisha and Agrawal C. P. (2017) this paper analyzed the administration of resource obligation in the financial area. The primary target of the investigation is to introduce the ideal blend of resources and responsibility of chose business banks in and Punjab National Bank and the leftover two 
are private banks to be specific ICICI Bank Limited and HDFC Bank Limited. To investigate the altering points of view, the examination was led for a time of five years (2011-2016)). In the current paper, an endeavor was had to assess the effect of ALM on liquidity and benefit of banks (examination among public and private area banks). For this, the correlation was made on various proportions like Net Profit Margin (NPM), Return on Equity (ROE), Net Interest Margin (NIM), Credit Deposit Ratio (CDR), Investment Deposit Ratio (IDR), and Cash Deposit Ratio.

Mukasinayobye Immaculee and Mulyungi Patrick (2018) this examination evaluated the impact of resource obligation the board on business banks of the African nation Rwanda. The particular targets were to decide the impact of capital ampleness, pay expansion, and working productivity on the monetary execution of business banks in Rwanda. The investigation embraced an engaging quantitative and correlational examination plan. The number of inhabitants in the investigation comprised of staff in the divisions of money, tasks, credit, and hazard in every one of the 11 business banks in Rwanda.

Prince Paul Antony K. and Manimegalai J. (2018) the analysis of Asset Liability Management in Indian bank was finished for the sample period from 2014 to 2018. It provided the essential framework to define measure, monitor, modify, and accomplish these risks through ratio analysis.

Thakker Khushboo and Chakraborty Tanupa (2018) this study examined Rate Sensitivity Assets, Rate Sensitivity Liabilities, Interest Sensitivity Ratio, Net Interest Income Ratio, and Net Interest Margin Ratio. Gap Analysis is also supported out to understand the impact of Asset Liability Management on the cost-effectiveness of banks for the top ten constituent banks for the period of 20072016.

Rekha P. (2018) the examination zeroed in on deciding the degree of relationship between resource obligations the executives and productivity of select Indian business banks. To consider the relationship factors Camel model was chosen to survey the general monetary strength of banks. The banks in India were ordered into the Public area, Private area, and Foreign banks. The examination utilizing board information for the year 2007-2016. Monetary pointers and distinctive factual devices like, Regression examination, Pearson connection, Anova, and graphic investigation have been performed to discover the relationship among factors.

Srividhya G. (2019) zeroed in on "An Analysis of Asset risk Management in Banking Sector with Special Reference of HDFC Bank" the current investigation endeavored with HDFC Bank to examine the hypothetical foundation of resource and obligation the board and to survey the profit and loss of the bank and furthermore assess the exhibition of balance sheet and accounting report of HDFC Bank.

Sharifi Sirus and Haldar Arunima et all (2019) the purpose of this paper was to observe the influence of credit risk mechanisms on the performance of credit risk management and the growth in non-performing assets (NPAs) of commercial banks in India.

Jasrai Lokesh (2020) textbook on "Data Analysis using SPSS" is a complete book on statistical tools and data analysis involving discriminant analysis.

\section{DISCRIMINANT ANALYSIS}

Linear discriminant functi0n analysis (i.e., discriminant analysis) performs a multivariate test of differences among group means. In addition, discriminant analysis helps in analyzing the minimum number of dimensions needed to describe these differences. The banks are given coding $(0,1)$ on the basis of the Interest Sensitivity Ratio which lies mostly between 0.9 to 1 .The banks having ratio above 0.99 or close to 1 are considered good and an ISR of 1 is ideal. But the banks which have less than 
that $(0.98)$ or less shows that the risk sensitive liabilities are more than the assets which becomes difficult for the banks to manage or make payments on time leading to mismatches.

Table 3.1: Banks Categorization

\begin{tabular}{|l|c|c|}
\hline BANKS & ISR & CODE \\
\hline Bank Of Baroda & 0.882898 & 0 \\
\hline Bank of India & 0.907956 & 0 \\
\hline Canara Bank & 0.953521 & 0 \\
\hline PNB & 0.966523 & 0 \\
\hline SBI & 1.001602 & 1 \\
\hline Allahabad Bank & 0.976641 & 0 \\
\hline Andhra Bank & 0.975589 & 0 \\
\hline CBI & 0.943005 & 0 \\
\hline Corporation Bank & 0.953569 & 0 \\
\hline Indian Bank & 1.009412 & 1 \\
\hline Axis Bank & 1.004032 & 1 \\
\hline HDFC & 1.043569 & 1 \\
\hline ICICI & 1.022114 & 1 \\
\hline Kotak Mahindra & 1.091034 & 1 \\
\hline Yes Bank & 1.012223 & 1 \\
\hline Federal Bank & 1.018497 & 1 \\
\hline IndusInd & 0.996533 & 1 \\
\hline RBL & 1.06496 & 1 \\
\hline Karur Vysya & 1.011586 & 0 \\
\hline Lakshmi Vilas Bank & 0.985366 & \\
\hline
\end{tabular}

(Source: Candidate's Calculations)

The Table 3.1 shows that 9 banks out of 20 banks are securing (0) and 11 banks are securing (1).

\section{VARIABLE VIEW}

The variables given below in Table 4.1 define the financial health of the bank and their mean value for the 10 years is taken for the data base.

Table 4.1: Variable View

\begin{tabular}{|l|l|}
\hline \multicolumn{1}{|c|}{ Variable Name } & \multicolumn{1}{c|}{ Variable Formulae } \\
\hline Asset composition (AC) & Risk Sensitive Assets/Total Assets \\
\hline Liability composition (LC) & Risk Sensitive Liabilities/Total Liabilities \\
\hline Return on Total Assets (ROTA) & Net profit/Total Assets \\
\hline Liquidity (LIQ) & Cash in Hand/Deposits \\
\hline Capital Adequacy Ratio (CAR) & $\begin{array}{l}\text { Tier1 Capital + Tier 2 Capital/Risk Weighted } \\
\text { Assets }\end{array}$ \\
\hline Net Interest Margin (NIM) & Net Interest Income/Total Assets \\
\hline Loan to Deposit Ratio (LDR) & Advances/Deposits \\
\hline
\end{tabular}




\section{DESCRIPTIVE STATISTICS}

Table 5.1: Descriptive Statistics

\begin{tabular}{|l|c|c|c|c|}
\hline & Mean & S.D. & Minimum & Maximum \\
\hline AC & 0.87 & 0.01 & 0.80 & 0.91 \\
\hline LC & 0.88 & 0.01 & 0.82 & 0.92 \\
\hline ROA & 0.11 & 0.03 & 0.06 & 0.75 \\
\hline LIQ & 0.01 & 0.00 & 0.00 & 0.02 \\
\hline CAR & 0.14 & 0.01 & 0.11 & 0.24 \\
\hline NIM & 0.03 & 0.00 & 0.02 & 0.02 \\
\hline LDR & 0.78 & 0.02 & 0.67 & 0.98 \\
\hline
\end{tabular}

The descriptive Statistics on the mean values of the variables is analyzed with the help of MS Excel.

\section{THE DISCRIMINANT LINEAR EQUATION}

DA includes the fortitude of a linear equation like regression that will foresee which group the case belongs to.

The form of the equation or function is: $D=v 1 X 1+v 2 X 2+v 3 X 3+\ldots+v i X i+a$

Where $\mathrm{D}=$ discriminate function

$\mathrm{v}=$ the discriminant coefficient or weight for that variable

$\mathrm{X}=$ respondent's score for that variable 2

$\mathrm{a}=$ constant

$\mathrm{i}=$ the number of predictor variables

So, the equation for the model is:

Banks $(0,1)=v 1$ AC1+v2LC2+ v3ROA3+v4LIQ4+v5CAR5+v6NIM6+v7LDR7+a

\section{THE DISCRIMINANT MODEL}

The grouping variable is taken as banks from table and the rest of the variable are taken as independents. Then the model is run on SPSS 20 and the results are given as follows:

\begin{tabular}{|c|c|c|c|}
\hline \multicolumn{4}{|c|}{ Analysis Case Processing Summary } \\
\hline \multicolumn{2}{|c|}{ Unweighted Cases } & $\mathrm{N}$ & Percent \\
\hline \multicolumn{2}{|l|}{\begin{tabular}{|l|} 
Valid \\
\end{tabular}} & 20 & 100.0 \\
\hline \multirow{4}{*}{ Excluded } & Missing or out-of-range group codes & 0 & .0 \\
\hline & $\begin{array}{l}\text { At least one missing discriminating } \\
\text { variable }\end{array}$ & 0 & .0 \\
\hline & $\begin{array}{l}\text { Both missing or out-of-range group codes } \\
\text { and at least one missing discriminating } \\
\text { variable }\end{array}$ & 0 & .0 \\
\hline & Total & 0 & .0 \\
\hline \multicolumn{2}{|l|}{ Total } & 20 & 100.0 \\
\hline
\end{tabular}




\begin{tabular}{|c|c|c|c|c|c|}
\hline & & & Group Statistics & & \\
\hline BANK & & Mean & Std. Deviation & Valid N & twise) \\
\hline & & & & Unweighted & Weighted \\
\hline & $\mathrm{AC}$ & .862222 & .0307318 & 9 & 9.000 \\
\hline & LC & .914333 & .0048734 & 9 & 9.000 \\
\hline & ROA & .070011 & .0067418 & 9 & 9.000 \\
\hline 0 & LIQ & .005296 & .0027000 & 9 & 9.000 \\
\hline & CAR & .121656 & .0061800 & 9 & 9.000 \\
\hline & NIM & .022209 & .0028253 & 9 & 9.000 \\
\hline & LDR & .718778 & .0269248 & 9 & 9.000 \\
\hline & $\mathrm{AC}$ & .874545 & .0195313 & 11 & 11.000 \\
\hline & $\mathrm{LC}$ & .858091 & .0296360 & 11 & 11.000 \\
\hline & ROA & .134818 & .2041401 & 11 & 11.000 \\
\hline 1 & LIQ & .009000 & .0040497 & 11 & 11.000 \\
\hline & CAR & .163091 & .0320420 & 11 & 11.000 \\
\hline & NIM & .029364 & .0054456 & 11 & 11.000 \\
\hline & LDR & .824455 & .0760057 & 11 & 11.000 \\
\hline & $\mathrm{AC}$ & .869000 & .0252587 & 20 & 20.000 \\
\hline Total & $\mathrm{LC}$ & .883400 & .0360050 & 20 & 20.000 \\
\hline lotal & ROA & .105655 & .1518110 & 20 & 20.000 \\
\hline & LIQ & .007333 & .0039083 & 20 & 20.000 \\
\hline & CAR & .144445 & .0316818 & 20 & 20.000 \\
\hline & NIM & .026144 & .0056837 & 20 & 20.000 \\
\hline & LDR & .776900 & .0790895 & 20 & 20.000 \\
\hline
\end{tabular}

\begin{tabular}{|l|c|c|c|c|c|}
\hline \multicolumn{7}{|c|}{ Tests of Equality of Group Means } \\
\hline & Wilks' Lambda & F & df1 & df2 & Sig. \\
\hline AC & .938 & 1.190 & 1 & 18 & .290 \\
\hline LC & .364 & 31.410 & 1 & 18 & .000 \\
\hline ROA & .953 & .897 & 1 & 18 & .356 \\
\hline LIQ & .766 & 5.498 & 1 & 18 & .031 \\
\hline CAR & .554 & 14.469 & 1 & 18 & .001 \\
\hline NIM & .587 & 12.655 & 1 & 18 & .002 \\
\hline LDR & .535 & 15.653 & 1 & 18 & .001 \\
\hline
\end{tabular}

\begin{tabular}{|l|c|c|}
\hline \multicolumn{3}{|c|}{ Log Determinants } \\
\hline BANKS & Rank & Log Determinant \\
\hline 0 & 7 & -76.659 \\
\hline 1 & 7 & -58.360 \\
\hline Pooled within-groups & 7 & -57.202 \\
\hline $\begin{array}{l}\text { The ranks and natural logarithms of determinants } \\
\text { group covariance matrices. }\end{array}$ \\
\hline
\end{tabular}




\begin{tabular}{|l|c|c|}
\hline \multicolumn{3}{|c|}{ Test Results } \\
\hline \multirow{3}{*}{ Box's M } & & 167.246 \\
\hline \multirow{3}{*}{ F } & Approx. & 3.321 \\
\cline { 2 - 3 } & df1 & 28 \\
\cline { 2 - 3 } & df2 & 1022.755 \\
\cline { 2 - 3 } & Sig. & .000 \\
\hline \multicolumn{2}{|c|}{ Tests null hypothesis of equal population covariance matrices. } \\
\hline
\end{tabular}

\begin{tabular}{|c|c|c|c|c|}
\hline \multicolumn{5}{|c|}{ Eigenvalues } \\
\hline Function & Eigenvalue & $\%$ of Variance & Cumulative \% & $\begin{array}{c}\text { Canonical } \\
\text { Correlation }\end{array}$ \\
\hline 1 & $3.406^{\mathrm{a}}$ & 100.0 & 100.0 & .879 \\
\hline \multicolumn{2}{|c|}{ a. First 1 canonical discriminant functions were used in the analysis. } \\
\hline
\end{tabular}

\begin{tabular}{|c|c|c|c|c|}
\hline \multicolumn{5}{|c|}{ Wilks' Lambda } \\
\hline Test of Function(s) & Wilks' Lambda & Chi-square & $\mathrm{df}$ & Sig. \\
\hline 1 & .227 & 21.503 & 7 & .003 \\
\hline
\end{tabular}

\begin{tabular}{|l|c|}
\hline \multicolumn{2}{|c|}{ Standardized Canonical Discriminant Function Coefficients } \\
\hline & Function \\
\cline { 2 - 2 } & 1 \\
\hline AC & -.671 \\
\hline LC & .998 \\
\hline ROA & .762 \\
\hline LIQ & .107 \\
\hline CAR & -.039 \\
\hline NIM & -.390 \\
\hline LDR & -.238 \\
\hline
\end{tabular}

\begin{tabular}{|c|c|c|c|c|c|}
\hline \multicolumn{6}{|c|}{ Classification Results $^{a}$} \\
\hline & & \multirow[t]{2}{*}{ BANKS } & \multicolumn{2}{|c|}{ Predicted Group Membership } & \multirow[t]{2}{*}{ Total } \\
\hline & & & 0 & 1 & \\
\hline \multirow{4}{*}{ Original } & \multirow{2}{*}{ Count } & 0 & 9 & 0 & 9 \\
\hline & & 1 & 0 & 11 & 11 \\
\hline & \multirow{2}{*}{$\%$} & 0 & 100.0 & .0 & 100.0 \\
\hline & & 1 & .0 & 100.0 & 100.0 \\
\hline
\end{tabular}

(Candidate's calculation) 


\section{RESULT ANALYSIS}

The test is run on $\mathrm{N}$ as 20 with no missing values.When the table of group statistics is seen the difference in mean value of the (0) bank and (1) bank is observed and it is found out that LC is (0.914)in 0 bank and 0.858 in 1 bank. ROA is (0.70)in 0 bank and (0.134) in 1 bank. LIQ is (0.005) in 0 bank and (0.009) in 1 bank. CAR is (0.121) in 0 bank and (0.163) in 1 bank. LDR is (0.718) in 0 bank and (0.824) in 1 bank. These variables are discriminating factors as seen from the table.The significance value in the boxplot is $(0.000<0.05)$ rejecting the null hypothesis that there is no difference between the parameters of 0 bank and 1 bank.

In the table of Canonical Discriminant Function the square of the canonical correlation value $(0.879 * 0.879=0.772)$ or $77.2 \%$ in the percentage form.It means that $77.2 \%$ of variance is shown between the parameters of 0 bank and 1 bank which is a good value.In the table of Wilk's Lambda the significance value is $(0.003<0.05)$ and the the Wilk's Lambda value is $(0.227)$ which is close to 0.If the value is close to 0 it means the group means are different which means that there is difference in the impacting variables of 0 bank and 1 bank.

On analyzing the table of Standardized Canonical Discriminant Function Coefficients the variableLC $(0.998)>\operatorname{ROA}(0.762)>\mathrm{LIQ}(0.107)>\mathrm{CAR}(-$ $0.039)>\operatorname{LDR}(-0.238)>\mathrm{NIM}(-0.39)>\mathrm{AC}(-0.671)$ it can be found that the LC is the most impacting factor and then ROA and then LIQ and then CAR and LDR in that order. The value of NIM and AC is very less so they are not discriminating so much.

Coming to the last part of analysis of Classification Result or famously known as Confusion Table. The Hit Ratio is $100 \%$ which means that there is $100 \%$ difference between the impacting factors of 1 bank and 0 bank. The cases which are classified as 0 bank and the cases which are classified as 1 bank are done correctly as seen from the table from the column of 0 and 1 which are given the value of 100-100 each.

I. The discriminant Function becomes as
Banks
$(0,1)=$
$(-0.671)^{*} \mathrm{AC}$
$+(0.998) * \mathrm{ROA}+(0.107) \mathrm{LIQ}+(-0.039) * \mathrm{CAR}+$
$(-0.390) * \mathrm{NIM}+(-0.238)^{*} \mathrm{LDR}$

\section{CRITICAL REGIONS}

Figure 1: ACE

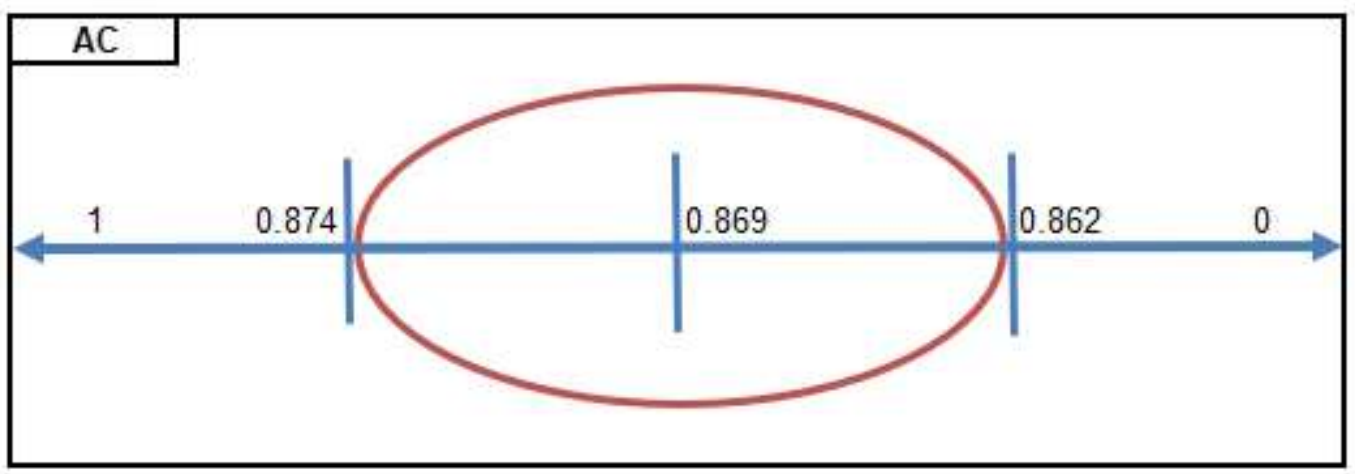


Figure 2: LC

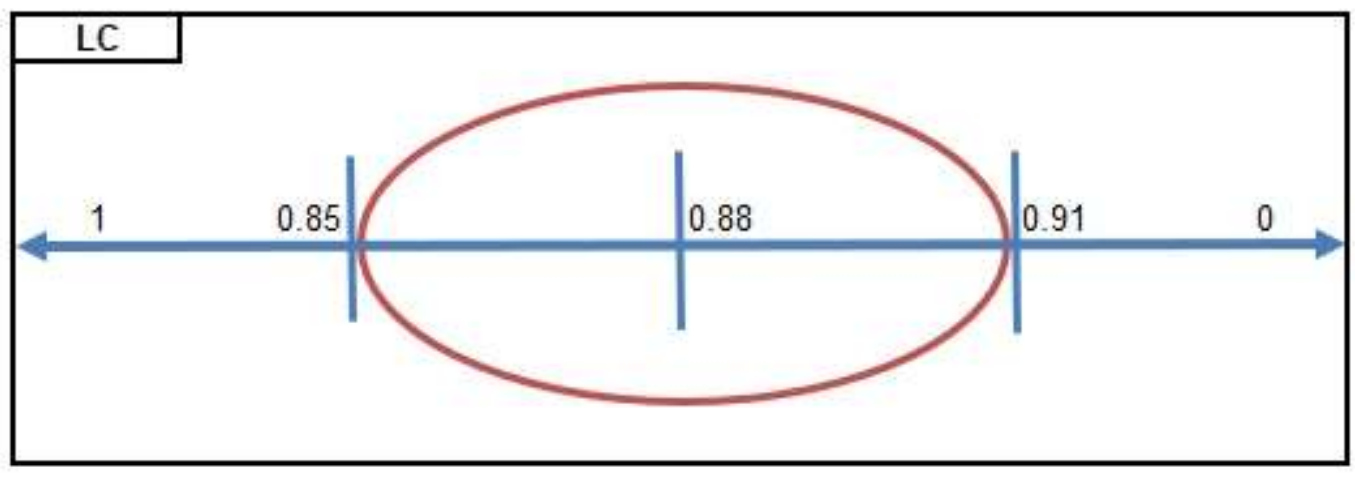

Figure 3: ROA

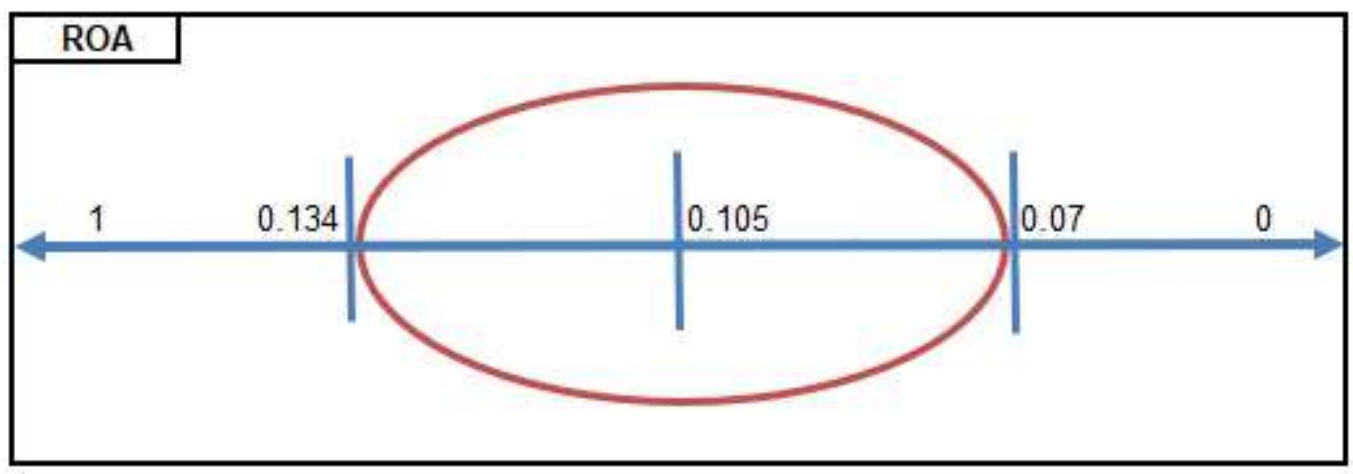

Figure 4: LIQ

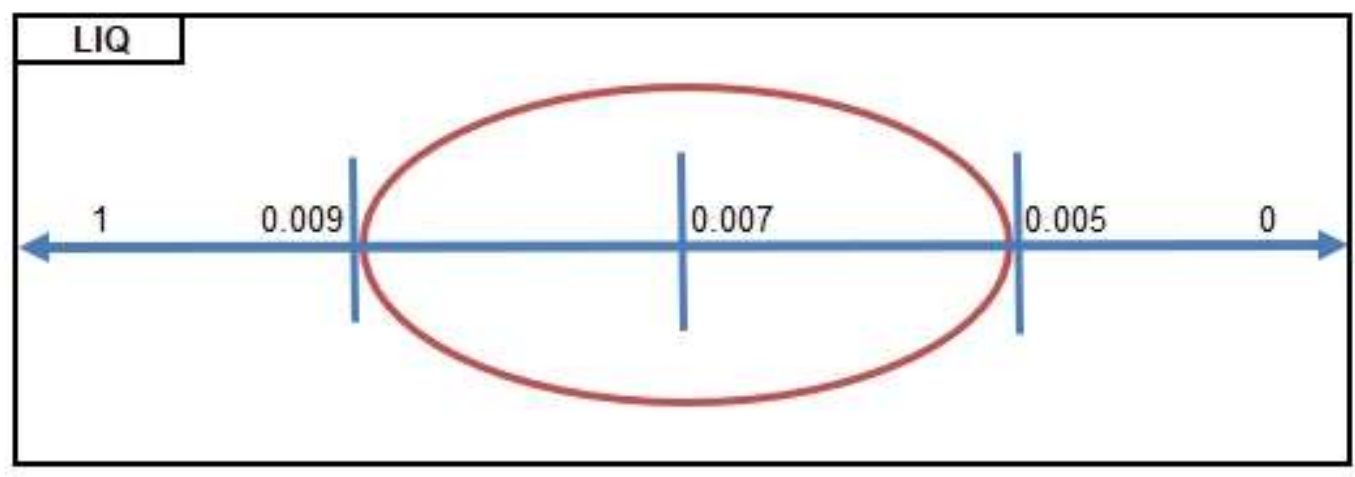

Figure 5: CAR

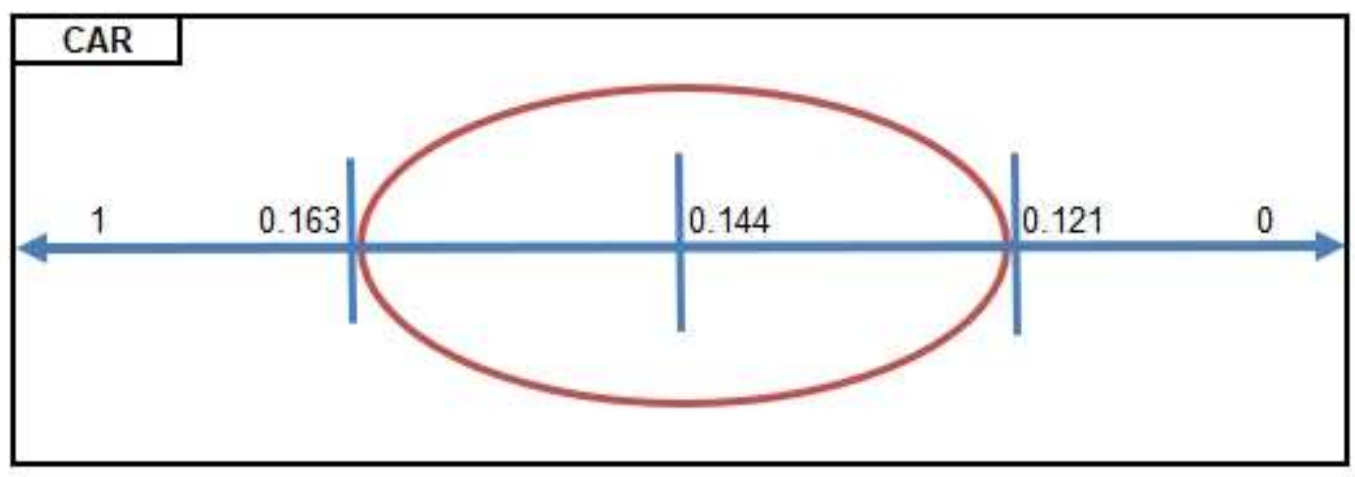


Figure 6: NIM

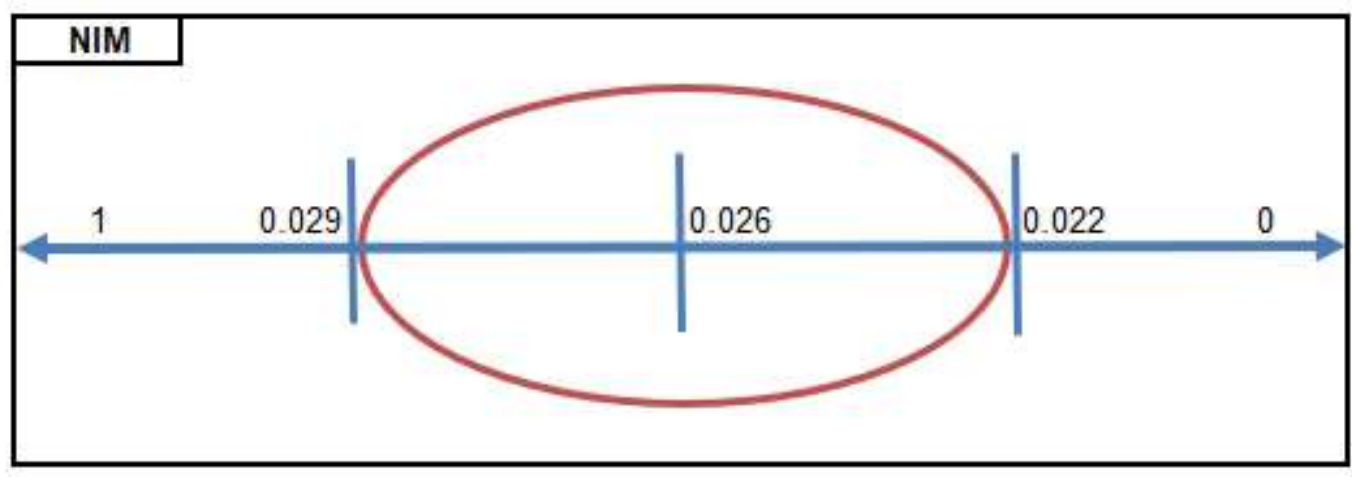

Figure 7: LDR

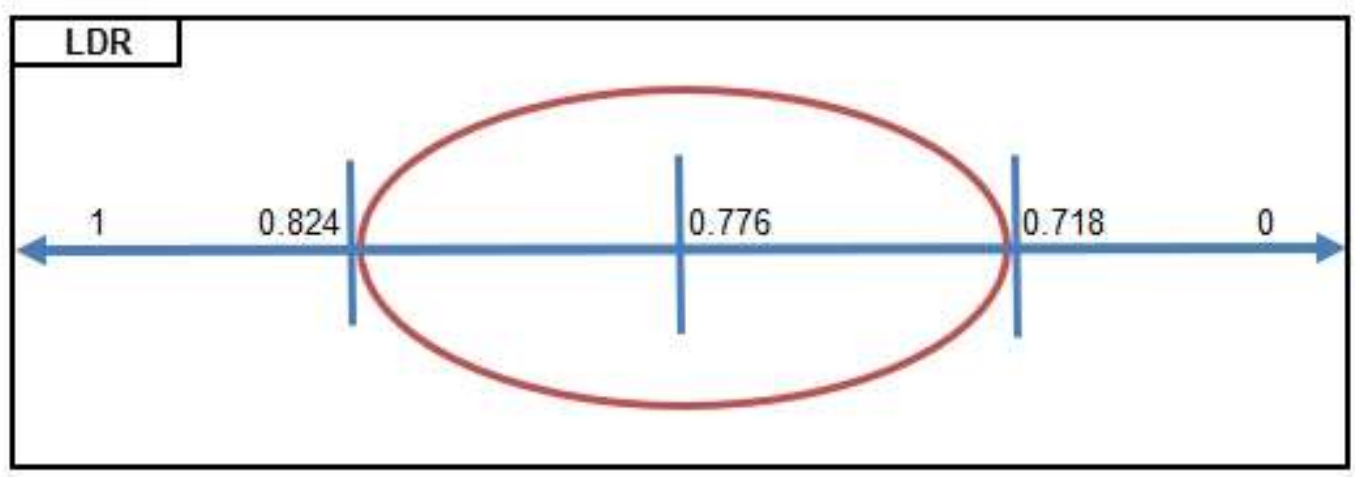

Table 9.1: Validation of Critical Region Results

\begin{tabular}{|c|c|c|c|c|c|c|c|c|c|c|}
\hline BANKS & RSL/TL & C.R. & ROA & C.R. & LIQ & C.R. & LDR & C.R. & CAR & C.R. \\
\hline BOI & 0.91 & 0 & 0.063 & 0 & 0.004 & 0 & 0.73 & 1 & 0.12 & 0 \\
\hline PNB & 0.91 & 0 & 0.068 & 0 & 0.005 & 0 & 0.75 & 1 & 0.12 & 0 \\
\hline LVB & 0.91 & 0 & 0.08 & 0 & 0.012 & 1 & 0.74 & 1 & 0.12 & 0 \\
\hline CBI & 0.911 & 0 & 0.067 & 0 & 0.006 & 0 & 0.67 & 0 & 0.11 & 0 \\
\hline BOB & $\mathbf{0 . 9 1}$ & $\mathbf{0}$ & $\mathbf{0 . 0 6}$ & $\mathbf{0}$ & $\mathbf{0}$ & $\mathbf{0}$ & $\mathbf{0 . 7 1}$ & $\mathbf{0}$ & 0.13 & 1 \\
\hline Canara & 0.915 & 0 & 0.072 & 0 & 0.003 & 0 & 0.71 & 0 & 0.13 & 1 \\
\hline Allahabad & 0.918 & 0 & 0.072 & 0 & 0.003 & 0 & 0.72 & 1 & 0.12 & 0 \\
\hline Andhra & 0.921 & 0 & 0.076 & 0 & 0.005 & 0 & 0.76 & 1 & 0.12 & 0 \\
\hline Corporation & 0.922 & 0 & 0.074 & 0 & 0.005 & 0 & 0.69 & 0 & 0.12 & 0 \\
\hline
\end{tabular}

The values for plotting in the figures of critical regions has been taken from the mean value of $(0,1$, total) of individual parameters from the group statistics table generated from the output of discriminant analysis. The value of (total) from the table is taken as median, value of (0) from the table is taken as lower value plotted towards the right hand side of the axis going towards 0 .The value of (1) is plotted as the higher value on the left hand axis of the graph towards 1.The significance of this analysis can be understood as the calculated mean values of the parameters which formed as the input values for the discriminant analysis has to be matched against the plotted values of critical region. After plotting it can be found out that the banks are falling in critical region demarcated by the red mark or not. If they are falling in critical region, the side is important whether it is towards 0 or towards 1.If it is towards 1 then it means that the banks though are in critical region but can be recovered if pay attention to the 
deterioting parameters. If the value is towards 0 , it means that the risk factor is high as the condition is deterioting and should be taken care of without any furtherdelay. Another condition that can be seen after plotting the values is when it is falling beyond critical region and that too towards 0 .This is the most risky situation for the banks and needs immidieate intervention of the government or any centralised financial body to assist the depleting banks. The same has been explained with the help of a flowchart given on the next page.

\section{FLOWCHART}

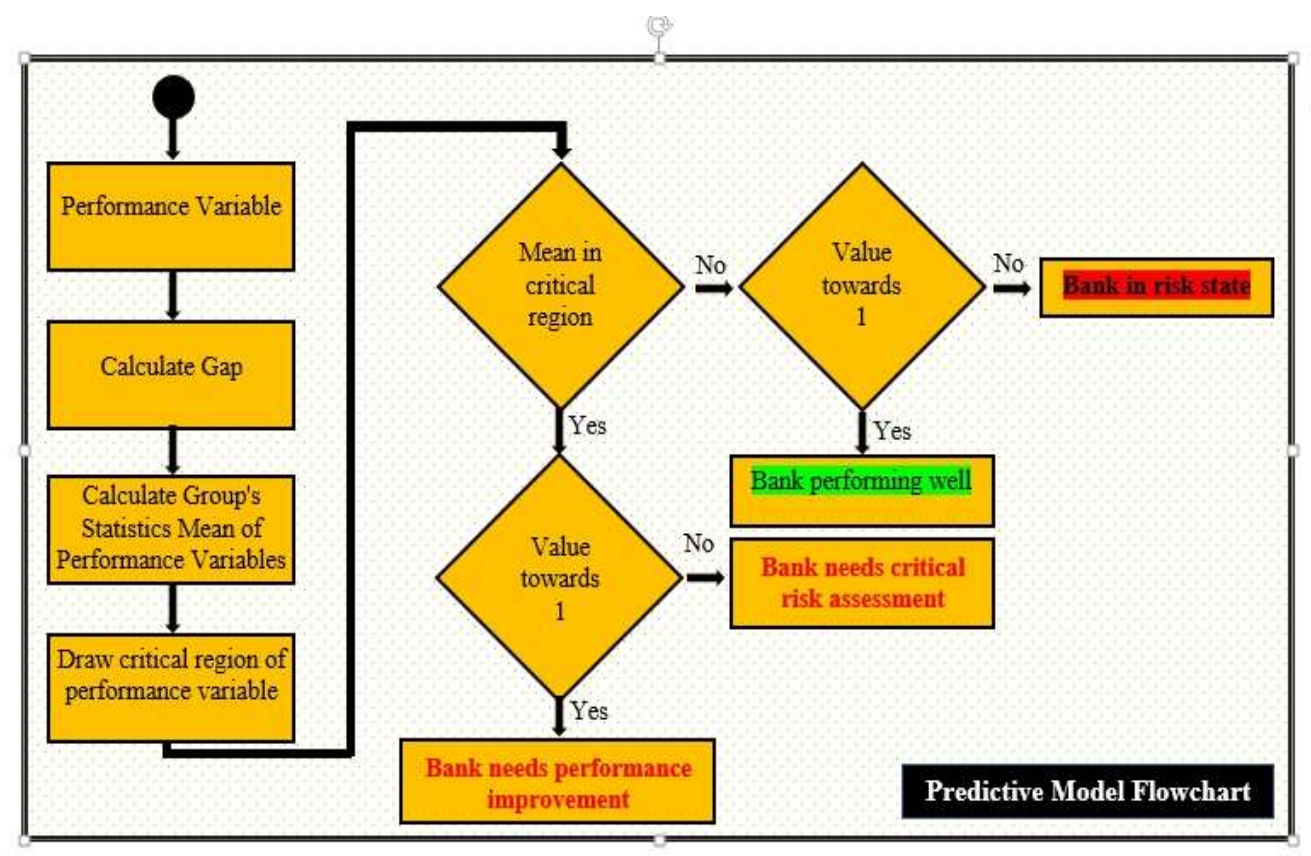

Figure 8: Discriminant Analysis Flowchart

\section{CONCLUSION}

Thus it can be concluded from the findings that the banks which are classified as 0 on the basis of Interest Sensitivity Ratio are rightly classified and also has discriminating factors as seen from the previous findings or data such as high LC, low ROA, low in LIQ, low in CAR and again low in LDR which are making these banks fall for asset liability mismatches and poor performance. The mean values of the performance variable for the 0 banks when put on critical region showed that for LC all the banks are beyond critical region towards 0 ,for ROA, Canara Bank, Allahabad Bank, Corporation Bank, Andhra Bank and Laxmi Vilas bank are falling beyond the critical region towards 0,for LIQ except for Laxmi Vilas bank, all the banks mean value is beyond the critical region towards 0,for LDR Canara bank ,BOB, Corporation Bank, CBI are beyond critical region towards 0 ,for $\mathrm{CAR}$ except for $\mathrm{BOB}$ and Canara Bank all the banks in 0 category have mean value beyond critical region towards 0 .

In the same way the banks which are classified as 1 on the basis of Interest Sensitivity Ratio are rightly classified as they are seen having Low LC, High ROA, high in LIQ, high in CAR and good in LDR as matched from the previous findings for validation of the model. .Thus it can be concluded that this model is fit for any bank and it can predict the discriminating factors which are important for the successful functioning of the bank and also simultaneously not so discriminating factors. This model will help the banks identify its performance 
impacting parameters which if managed beforehand will keep a check on them and prevent them from failing.

\section{REFRENCES}

\section{Research Papers}

A. Karthigeyan, V. Mariappan- "Liquidity Risk Management in Select Private Sector Banks in India: A Gap Analysis Approach", International Journal Of Management \& Business Studies, IJMBS Vol. 7, Issue 3, July - Sept 2017 ISSN.

A.Karthigayam, V. mariyappan and B. Rangaiyah (2013) "Asset- liability Management in Indian private sector banks "- A canonical Correlation analysis. Vol 4, issue 5, Sep- oct (2013) pg 6-13, International Journal of management.

Acharya, Shankar, 2002, "Indian: Crisis, Reforms and Growth in Nineties", working paper no.139, Standard University.

Amit kumar meena and joydipdhar (2014) international research journal of business and management., IRJBM - (www.irjbm.org) Volume No - VIII, January - 2015 , Issue - 1 Page 42 (C) Global Wisdom Research Publications.

Anita Makker and Shveta Singh.Assistant (2013.) professor, Haryana school of Business, "Interest rate risk of selected Indian commercial banks, An Application of GAP Analysis Model." The IUP journal of bank management, vol. XII, No 4.

Anurag B singh, Ms Priyanka Tandon.(2012)" Asset - liability Management in Indian banking industry", Asia pacific journal of Marketing and management review,vol1, No1, ISSN 2319-2836.

B M Misra and Sarat Dhal (2012) "Pro-cyclical Management of Banks' Non-Performing Loans by the Indian Public Sector Banks," https://www.researchgate.net/publication/238 740095.

B S Bodla and Richa verma Bajaj (2010)," An analysis of efficiency of private sector banks," The IUP Journal of Bank Management, 2010, vol. IX, issue $1 \& 2$, pages $60-82$.

B. Charumathi, "Asset Liability Management in
Indian Banking Industry - with special reference to Interest Rate Risk Management in ICICI Bank" proceeding of the World Congress Engineering 2008 Voll. II, WCE 2008, London, U.K., July 2-4, 2008.

Belete, T., "Asset Liability Management and Commercial Banks Profitability in Ethiopia," Research Journal of Finance and Accounting, Vol.4 (10), 2013. 26. PTS Murthy (Oct 2014.) The Indian banker. vol,II, No 3, 26.

Chaudary V and Tandon S (2011), "Performance of Commercial Banks in India during Post Liberalization," International Journal of Multidisciplinary Research, Volume I, December (online Journal).

Choudhry M. (2011)" Bank Asset liability and Liquidity Risk Management" in Mitra G., Schwaiger K. (eds) Asset and Liability Management Handbook. Palgrave Macmillan, London.

Cyngus (2004), "Indian Banking," Hyderabad, 2004.

Dash, M. \& Pathak, R.,"A Linear Programming Model for Assessing Asset Liability Management in Banks," The IUP Journal of Financial Risk Management, Vol.8 (1), March, 2011.

Dash, M., Venkatesh, K.A. \& Bhargav, B.D., “An Analysis of Asset liability Management in Indian Banks"( http://papers.ssrn.com/sol3/papers .cfm?abstract_id $=1760786$ )

Deborah.K.Dilley, (2008) "Essentials of banking "John Wiley and sons", New Jersey, pp 6.

Deepak Kumar Sharma, Anju Saharan- "Analysis of Liquidity of Nationalised Banks in India," International Journal of Research in Finance and Marketing, Volume 6, Issue 4 (April, 2016).

Dr. G. Srividhya. (2019). "An Analysis of Asset liability Management In Banking Sector With Special Reference Of HDFC Bank." Think India Journal, 22(14), 1240012406. Retrieved from https://journals.eduindex.org/index.php/think -india/article/view/16210.

Dr. K. Prince Paul Antony and J.Manimegalai, International Journal of Business Administration and Management. ISSN 2278-3660 Volume 8, 
Number 1 (2018), pp.1-9.

Evans Tee, - IOSR Journal of Economics and Finance (IOSR-JEF) e-ISSN: 2321-5933, p-ISSN: 2321-5925. Volume 8, Issue 3 Ver. IV (May - June 2017), PP 09-14.

Immaculee Mukasinayobye, Dr Patrick Mulyungi ,International Journal of Science and Research (IJSR) ISSN: 2319-7064, Volume 7 Issue 11, November 2018.

Jyotsna sethi \& Nishwan Bhatia (2008), “Elements of banking and insurance" PHI learning Pvt Ltd, New Delhi, pp 6, 7.

Kalam, A.P.J. and Rajan, Y.S. (1998), “India 2020: A Vision for the New Millennium", Penguin Books, New Delhi.

Kamath, K.V., (2003), “Indian Banking Sector: Challenges and Opportunities", Vikalpa, Volume 28, No. 3, July- September, IIM, Ahemdabad.

Khushboo Thakker and Tanupa Chakraborty(2018)" Asset Liability Management in Commercial Banks in India" Springer Nature Singapore Pte Ltd. 2018 N. R. Bhanumurthy et al. (eds.), Advances in Finance \& Applied Economics, https://doi.org/10.1007/978-981-13-1696-8_18.

Kosmasnjanike (2009)" The impact of effective credit risk management on bank survival" Journal of the university of petrosani, economics, Vol, 9(2) " Pg No 173-184. 18. A.Adam (2009) Adam Alexander (2009) hand book of ALM from model to optimal return strategic series. Wiley finance series Chachester johe wiley.

Mandeep kaur \& Samriti kapoor (2012) Basel III framework:" A road to resilient Banking system." The management accountant, pg no 938.

Mr. M. Devendra and Prof. P. Mohan Reddy"Interest Rate Sensitivity Management in Select Commercial Banks in India," IJARIIE-ISSN (O)2395-4396, Vol-3 Issue-4 2017.

Mrs. Sreekala \& Dr.V. Santi (2011) “A Study on Asset Liability Management in salem cooperative banks." www.mbainfoline.com.

Narayan Baser (2014) "Asset Liability Management in commercial banks", Asian journal of banking and finance, vol 4, issue, $2 \mathrm{Pg}$ 165-177.

Nimisha Agrawal, C. P. Agrawal, “A Note on Asset and Liability Management of

P. Sheela \& Ms Tejeswini Bastray (2014) international research journal of business and management. IRJBM - (www.irjbm.org) Volume No - VIII, January - 2015, Issue - 1 Page 42 (C) Global Wisdom Research Publications.

P.Rekha, 2018," A Study on Asset Liability Management and Profitability of select Indian Commercial Banks" International Journal of Enhanced Research in Management \& Computer Applications ISSN: 2319-7471, Volume 7 Issue 3. 58. Krishna Prasada, Dr. Suprabha K.Rb ,2014," Anomalies in Maturity Gap: Evidence from Scheduled Commercial Banks in India" Procedia Economics and Finance 11 ( 2014 ) $423-430$

Patnaik, I. \& Shah, A. "Interest-Rate Risk in the Indian Banking System", Working paper no.92, Indian Council For Research On International Economic Relations, New Delhi, 2002.

Poongavanam S, (2011), “Nonperforming Assets: Issues, Causes and Remedial Solution", Asian Journal of Management Research, Vol. 2, Issue 1, pp 123-132.

Prasad Bhavani GV \& veena (2011), "NPAs Reduction Strategies for Commercial Banks in India" IJMBS, Vol. 1, September 2011, pp 47-53.

Prasad, K., Suprabha, K.R., “Anomalies in Maturity GAP: Evidence from Scheduled Commercial Banks in India", Procedia Economics and Finance, Vol.11, 2014.

Prof. Kanhaiya Sngh (2013) Asset- liability Management in Banks"A Dynamic Approach ALM", AIMA journal of Management \& Research, Vol7, ISSN 0974-497.

R Umarani, M Jayanthi- "An Analysis of Asset liability Management In Indian Banks", IJBARR Vol. 1 Issue.11, July - Sep, 2015 Page180.

R. Gandhi (June 2014), Risk management, Reference. RBI Bulletin. 2014, pp. 36 -38

R. Vaidyanathan (1999) "Assets and liabilities management issues and trends in Indian Context" ASCI journal of Management, 29(1) An analysis of the efficiency of private sector banks 
in India, IUP journal 2010., Pg No 39- 48.

R.BharathVajan, K.P.Thooyamani, Vignesh A- “A Study on Asset Liability Management, International Journal of Pure and Applied Mathematics," Volume 116 No. 14 2017, 249-253.

Ram Mohan T.T (2002) "Dergulation and performance of Public sector banks" Economic and political weekly, 36, 4, $265-67$.

Ranjan and Nallari (2004)" Study of Asset Liability Management in Indian banks, canonical correlation analysis," Spandan.

Rao A.V (2005) "ALM system in banks," Treasury management.

S. P. Joshi1 \& Dr. R. V. Sontakay, Imperial Journal of Interdisplinary research (IJIR), vol3, Issue-6, 2017, ISSN: 2454-1362, http://www.onlinejournal.in. 45. Dhawan Anny (2016), "Performance Evaluation of District Cooperative Banks of Punjab- A CAMEL Model Analysis," An Unpublished Thesis submitted to IKG-PTU.

Sanjib Kumar Pakira- Growth Performance Analysis "A Comparative Study between SBI and HDFC Bank Limited," American Journal of Theoretical and Applied Business, ISSN: 2469-7834(Print); ISSN: 2469-7842 (Online).

Kanhaiya Singh,Rajesh Gupta (2017) AComparitive Study of Implementation ofBasel-III norms-an analysis of select countries, Int. J. Business and Globalisation, Vol. 19, No. 3, pp.433-453.

Singh, K. And Gupta, R. (2017) 'A comparative study of implementation of Basel 3 norms - an analysis of select countries', Int. J. Business and Globalization, Vol. 19, No. 3, pp.433-453

Selected Commercial Banks in India," Indian Journal of Applied Research: Volume7 |Issue2| February 2017.

Selvin surjith FP \& N.sathyanarayana. (2014), International journal of advanced research in management and social sciences. Vol 3, No 7.

\section{WEBSITES}

1. data.worldbank.org

2. shodhganga.inflibnet.ac.in
3. www.allbankingsolutions.com

4. wWw.researchgate.net

5. www.sciencedirect.com

6. www.scribd.com

7. www.ssrn.com

8. www.rbi.org.in

9. www.simplywall.st/about

10. www.moneycontrol.com

11. www.economictimes.indiatimes.com

12. www.investpedia.com 